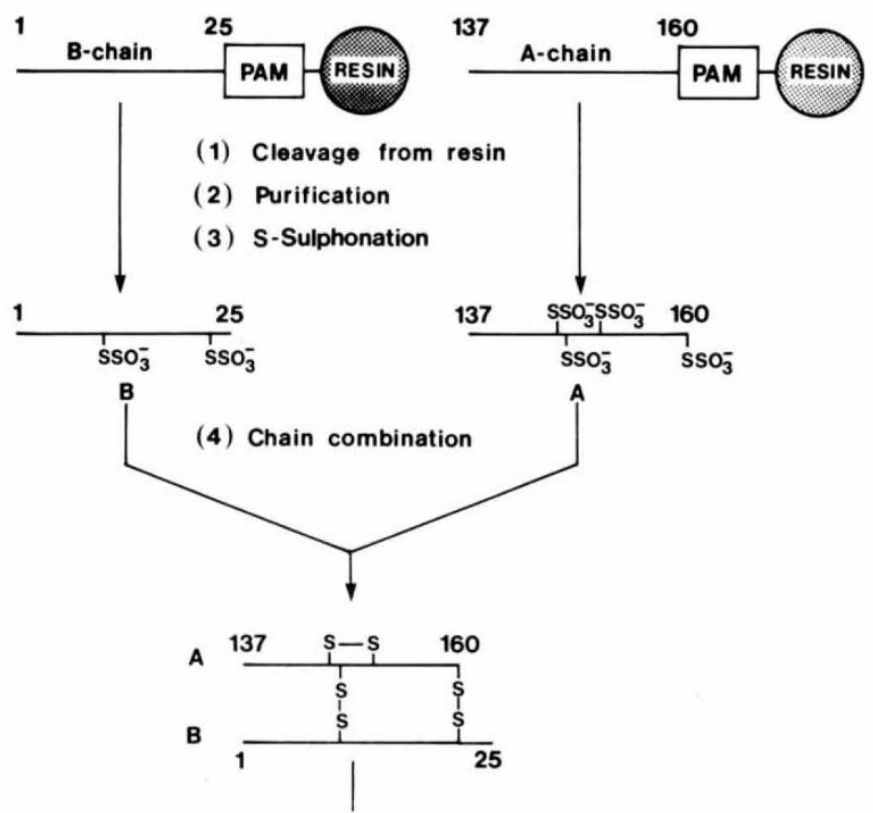

5) Bioassay<smiles>[3H][3H]</smiles>

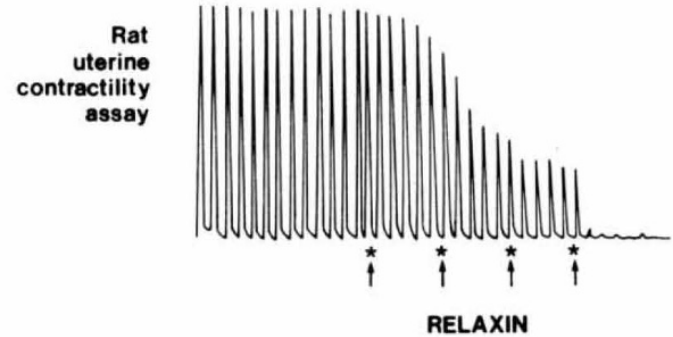

Fig. 4 Chemical synthesis of a peptide with relaxin bioactivity based upon the putative human relaxin sequence deduced from a genomic clone. The A chain (Arg 137-Cys 160) and the B chain segment (Lys 1-Ser 25) were assembled separately on a phenylacetamidomethyl (PAM) polystyrene resin support using procedures previously described ${ }^{15}$. Following cleavage from the resin and purification the peptides were $S$-sulphonated and combined using the insulin chain combination conditions described by Chance and Hoffmann ${ }^{36}$. Specific relaxin-like biological activity was detected in the rat uterine contractility assay ${ }^{21}$ by adding increasing concentrations of the combination mixture at the positions marked by asterisks. In preliminary experiments combination yields and specific activities relative to porcine relaxin of the order of 1 to $3 \%$ were achieved. In control experiments the synthetic A and B chain preparations were each separately exposed to the conditions for chain combination and assayed. There was no inhibition of uterine contractility indicating the absence of nonspecific toxic effects on the rat myometrium.

has not been possible because of the scarcity of human ovarian tissue during pregnancy and the extremely low abundance of relaxin specific mRNA in the non-pregnant state ${ }^{22}$. However, restriction fragments of the human relaxin gene available from the present work could be used to screen cDNA clone banks with some hope of finding relaxin-specific cDNA clones in low abundance. In the meantime, synthetic human relaxin can be made available for a variety of physiological and clinical studies bearing on the established functions of this hormone in remodelling connective tissues ${ }^{23,24}$ and in regulating uterine motility $y^{5,21}$. This may lead to the development of clinical treatments to alleviate some of the problems encountered at childbirth. In addition, several more speculative functions of relaxin in ovulation ${ }^{22,25}$, sperm penetration ${ }^{26}$ or blastocyst implantation $^{27}$ can be further investigated.

We thank D. Scanlon, J. Gorman and C. Southwell for assistance with primer synthesis and B. Kemp and S. Denney for the bioassay data. Dr T. Maniatis kindly provided the human genome library and R. Staden the computer programs for DNA sequence analysis. The research was carried out under NIH/ASCORD containment guidelines for recombinant DNA techniques and was supported by grants from the National Health and Medical Research Council of Australia, the Myer Family Trusts, the Ian Potter Foundation, the Howard Florey Biomedical Foundation and by NIH grant HD11908.

Received 20 September; accepted 15 December 1982.

1. Schwabe, C., McDonald, J. K. \& Steinetz, B. G. Biochem. biophys. Res. Commun. 75, 503-510 (1977).

2. James, R., Niall, H., Kwok, S. \& Bryant-Greenwood, G. Nature 267, 544-546 (1977).

3. John, M. J., Borjesson, B. W., Walsh, J. R. \& Niall, H. D. Endocrinology 108, 726-729 (1981).

4. Schwabe, C., Gowan, L. K. \& Reinig, J. W. Ann. N.Y. Acad. Sci. 380, 6-12 (1982)

5. Porter, D. G. Biol. Reprod. 7, 458-465 (1972).

6. Hudson, P., Haley, J., Cronk, M., Shine, J. \& Niall, H. Nature 291, 127-131 (1981).

7. Haley, J. et al. DNA 1, 155-162 (1982).

8. Chan, S. J., Keim, P. \& Steiner, D. F. Proc. natn. Acad. Sci. U.S.A. 73, 1964-1968 (1976).

9. Lawn, R. M., Fritsch, E. F., Parker, R. C., Blake, G. \& Maniatis, T. Cell 15, 1157-1174 (1978)

10. Maniatis, T. et al. Cell 15, 687-701 (1978)

11. Southern, E. M. J. molec. Biol. 98, 503-517 (1975).

12. Mount, S. M. Nucleic Acids Res. 10, 459-472 (1982).

13. Bell, G. I. et al. Nature 284, 26-32 (1980).

14. Steiner, D. F., Quinn, P. S., Chan, S. J., Marsh, J. \& Tager, H. S. Ann. N.Y. Acad. Sci. 343, 1-16 (1980).

15. Tregear, G. et al. in Peptides: Synthesis, Structure, Function (eds Rich, D. H. \& Gross, E.) 249-252 (Pierce Chemical Co., Rockville, Illinois, 1981).

16. Bedarkar, S., Turnell, W. G., Blundell, T. L. \& Schwabe, C. Nature 270, 449-451 (1977). 17. Isaacs, N. et al. Nature 271, 278-281 (1978),

18. Hirs, C. H. W., Moore, S. \& Stein, W. H. J. biol. Chem. 219, $623-630$ (1956).

19. Light, A. Meth. Enzym. 11, 426-436 (1967).

20. Du, Y-C., Minasian, E., Tregear, G. W. \& Leach, S. J. Int. J. Peptide Protein Res. 20, 47-54 (1982).

21. Wiqvist, N. \& Paul, K. G. Acta endocr. 29, 135-136 (1958)

22. Bryant-Greenwood, G. D., Jeffrey, R., Ralph, M. M. \& Seamark, R. F. Biol. Reprod. 23, 792-798 (1980).

23. Weib, M., Magelschmidt, M. \& Struck, H. Horm. Metab. Res. 11, 408-410 (1979).

24. Stone, M. L., Sedlis, A. \& Zuckerman, M. B. Ann N. Y. Acad. Sci. 75, 1011-1015 (1959).

25. Chihal, H. J. \& Epsey, L. L. Endocrinology 93, 1441-1445 (1973).

26. Loumaye, E., Decooman, S. \& Thomas, K. J. Clin. Endocr. Metab. 50, 1142-1143 (1980).

27. Hisaw, F. L., Hisaw, F. L. Jr \& Alden, D. B. Endocrinology 81, 375-385 (1967).

28. Taylor, J. M., Illmensee, R. \& Summers, J. Biochim. biophys Acta 442, 324-330 (1976).

29. Benton, W. D. \& Davis, R. W. Science 196, 180-182 (1977).

30. Denhardt, D. T. Biochem. biophys. Res. Commun. 23, 641-646 (1966).

31. Yamamoto, K. R., Alberts, B. M., Benzinger, R., Lawhorne, L. \& Treiber, G. Virology 40, 734-744 (1970).

32. Sanger, F., Coulson, A. R., Barrell, B. G., Smith, A. J. H. \& Roe, B. A. J. molec. Biol. 143, $161-178(1980)$.

33. Sanger, F., Nicklen, S. \& Coulson, A. R. Proc natn. Acad. Sci. U.S.A. 74, 5463-5467 (1977).

34. Maxam, A. M. \& Gilbert, W. Proc. natn. Acad. Sci. U.S.A. 74, 560-564 (1977).

35. Beaucage, S. L. \& Caruthers, M. H. Tetrahedron Lett. 22, 1859-1862 (1981).

36. Chance, R. E. \& Hoffmann, J. A. Australian Patent Appl. No. 68844/81.

\section{Mitochondrial DNA sequences in the nuclear genome of a locust}

\author{
Gerd Gellissen*, J. Y. Bradfield, B. N. White \\ \& G. R. Wyatt
}

Department of Biology, Queen's University, Kingston, Ontario, Canada K7L 3N6

The endosymbiotic theory ${ }^{1}$ of the origin of mitochondria is widely accepted, and implies that loss of genes from the mitochondria to the nucleus of eukaryotic cells has occurred over evolutionary time ${ }^{2,3}$. However, evidence at the DNA sequence level for gene transfer between these organelles has so far been limited to a single example, the demonstration that a mitochondrial ATPase subunit gene of Neurospora crassa has an homologous partner in the nuclear genome ${ }^{4}$. From a gene library of the insect, Locusta migratoria, we have now isolated two clones, representing separate fragments of nuclear DNA, which contain sequences homologous to the mitochondrial genes for ribosomal RNA, as well as regions of homology with highly repeated nuclear sequences. The results suggest the transfer of sequences between mitochondrial and nuclear genomes, followed by evolutionary divergence.

* Present address: Institut für Zoologie III, Universităt Düsseldorf, Universitätsstrasse 1, 4000 Düsseldorf 1, FRG. 
Fig. 1 Structures of locust nuclear DNA clones $(\boldsymbol{A})$ and mitochondrial DNA $(B) . \boldsymbol{A}$, nuclear DNA clones. $\lambda \mathrm{Lm} 12$ and $\lambda \mathrm{Lm} 14$ were obtained from a Charon 4 EcoRI library of Locusta DNA ${ }^{5}$. Subclones in plasmid pAT153, grown in Escherichia coli HB101, were: from $\lambda \mathrm{Lm} 12$, the entire insert of $11.3 \mathrm{~kb}$ (pLmE12) and a $0.8-\mathrm{kb}$ fragment (pLmEH120.8 ); from $\lambda \operatorname{Lm14}$, two fragments of 4.8 and $8.5 \mathrm{~kb}$ (pLmE14-4.8 and pLmE14-8.5). $\mathrm{L}$ and $\mathrm{R}$ indicate the left and right arms of $\lambda$, respectively. In pLmE14-8.5, the HinfI sites (not yet fully mapped) are omitted. Cross-hatched bars indicate regions that include sequences homologous with mitochondrial DNA (see text). Sequences homologous to the 1.4-kb mitochondrial rRNA (marked by solid bars) were identified by hybridization with cDNA against fat body RNA $^{12}$. Lines limited by triangles $(\Delta-\Delta)$ indicate fragments that include highly repetitive nuclear sequences. B, Locusta mitochondrial DNA. DNA was isolated from fat body and flight muscle mitochondria $^{13}$ and partially purified by centrifugation in $\mathrm{CsCl}$ gradients with ethidium bromide ${ }^{14}$, followed by extraction with phenol and chloroform. The cross-hatched bar marks the region that includes sequences homologous with the cloned nuclear DNA sequences; only the restriction sites relevant to localizing this region are shown. EcoRI fragments of 8.0, 3.9, 2.3 and 1.4 kb, HindIII fragments of 14.2 and $1.5 \mathrm{~kb}, \mathrm{Xbal}$ fragments of 5.6, 4.4, 2.6, 2.0 and $1.2 \mathrm{~kb}$ (see Fig. 3B, panel 1) and several Hinfl fragments, but no sites for BamHI or SalI, were found.

In the course of a study of gene expression during development in $L$. migratoria, we prepared a DNA library by partial digestion of locust fat body DNA with Eco RI, selection for 18-20-kilobase (kb) fragments, and cloning in $\lambda$ Charon 4 (ref. 5 ). This library was screened with cDNAs prepared against RNA from fat body of reproductive females, adult males and fifth instar larvae. A group of six clones showed strong hybridization, indicating homology with prevalent sequences in all three cDNA probes. They also showed some degree of homology with each other when tested by dot hybridization with a plasmid subcloned probe.

Four of these clones, tested on Northern blots of locust tissue RNA, showed homology with two RNA species of 1.4 and $0.8 \mathrm{~kb}$. Two clones, $\lambda \mathrm{Lm} 12$ and $\lambda \mathrm{Lm} 14$, were selected for study, and sequences from them were subcloned in a plasmid (Fig. 1A). Restriction mapping showed quite distinct patterns for $\lambda \mathrm{Lm} 12$ and $\lambda \mathrm{Lm} 14$.

Because 1.4 and $0.8 \mathrm{~kb}$ are close to the sizes of Locusta mitochondrial ribosomal $\mathrm{RNAs}^{6}$, and because a poly $(\mathrm{A})$ sequence present in the larger mitochondrial rRNA of another insect, Drosophila ${ }^{7}$, provides for initiation of cDNA with an oligo(dT) primer, we examined the possibility that these clones were of mitochondrial origin. Northern blotting showed that the two RNA components to which pLmE14-4.8 showed homology (Fig. $2 A$ ) were also homologous with mitochondrial DNA (Fig. $2 B$ ), and are presumably mitochondrial rRNAs. They were present in several locust tissues but especially abundant in flight muscle, which is rich in giant mitochondria. pLmE12 gave the same reaction (not shown), but pLmEH120.8 hybridized with the larger rRNA only (Fig. $2 C$ ).

The suggestion of mitochondrial origin for the $\lambda$ clones was not supported, however, by comparison of the restriction maps. Mitochondrial DNA, prepared either from fat body or flight muscle mitochondria, was found to be a circular molecule of $\sim 16 \mathrm{~kb}$, similar to that of other animals (Fig. $1 B$ ). The restriction map does not match that of $\lambda \mathrm{Lm} 12$ or $\lambda \mathrm{Lm} 14$. However, as the clones contained sequences homologous to mitochondrial rRNA, they must possess some relationship to the mitochondrial genome.

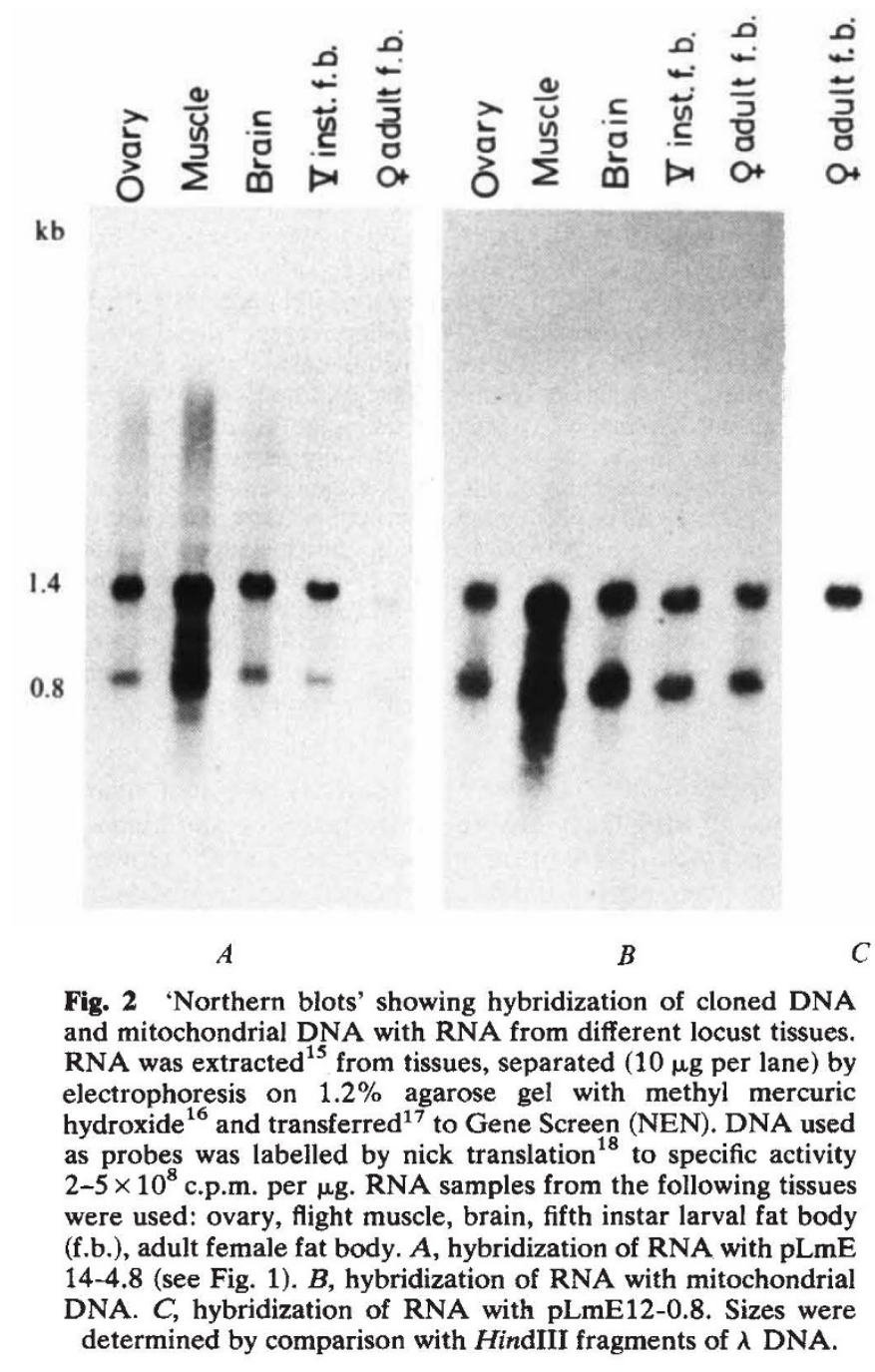


Fig. 3 Hybridization of locust nuclear $(A)$ and mitochondrial $(B)$ DNA to cloned probes. $A$, hybridization of nuclear DNA. DNA was prepared ${ }^{19}$ from fat body nuclei, digested with EcoRI and electrophoresed (15 $\mu \mathrm{g}$ per lane) on $0.8 \%$ agarose gel in $40 \mathrm{mM}$ Tris- $\mathrm{HCl}$ ( $p \mathrm{H} \mathrm{8.3),} 33 \mathrm{mM} \mathrm{NaOH}, 1 \mathrm{mM}$ EDTA. Fragments were transferred to diazobenzyloxymethyl paper ${ }^{20}$ and hybridized $(5 \times$ SSC, $50 \%$ formamide, $2 \times$ Denhardt's solution, $50 \mathrm{mM}$ phosphate $p \mathrm{H} 6.5,42^{\circ} \mathrm{C}, 12 \mathrm{~h}$, followed by repeated washing in $0.1 \times \mathrm{SSC}$ at $65^{\circ} \mathrm{C}$ ) to cloned DNAs labelled by nick translation. Panel 1 , probed with pLmE12 (see Fig. 1); 2, probed with pLmE14-4.8; 3 , probed with pLmE14-8.5. B, hybridization of partially purified mitochondrial DNA, digested with restriction enzymes indicated. Panel 1, stained gel showing mitochondrial fragments; 2 , blot of same hybridized with pLmE12; 3, hybridization with pLmE144.8. Size scales: left, $\lambda$ HindIII fragments; right, EcoRI fragments of mitochondrial DNA.

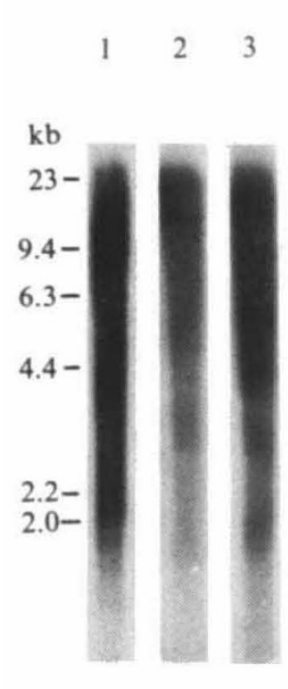

A

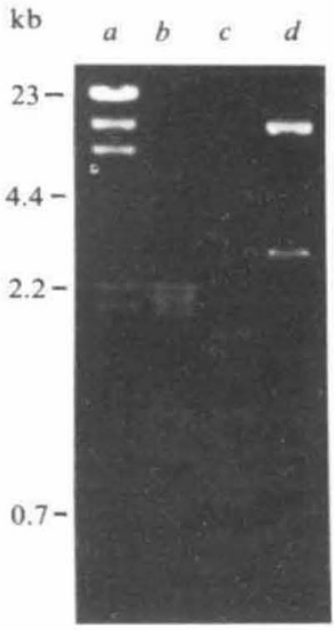

1

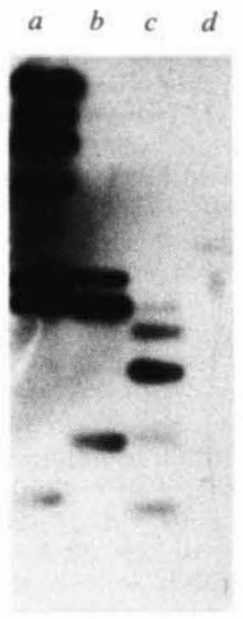

2

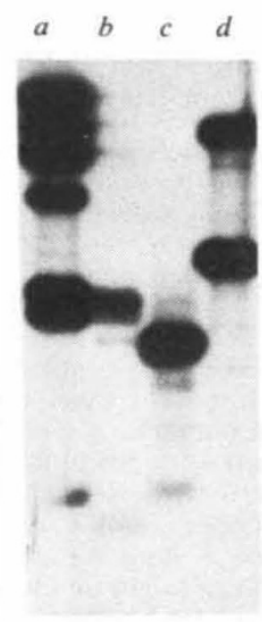

3

Fig. 4 Homologies between the cloned DNA sequences and nuclear and mitochondrial DNAs. $A$, Southern blots. Digests of cloned DNAs were electrophoresed on $1.5 \%$ gel and transferred to nitrocellulose filters ${ }^{17}$. Panel 1 , gel stained with ethidium bromide; 2 , hybridization $(3 \times \mathrm{SSC}, 10 \times$ Denhardt's solution, $65^{\circ} \mathrm{C}, 12 \mathrm{~h}$, followed by washing as in Fig. 3) of blot with mitochondrial DNA, prepared as described in Fig. 1 legend and labelled by nick translation; 3 , hybridization with nuclear DNA, extracted from nuclei from adult female locust fat body ${ }^{21}$, purified in a $\mathrm{CsCl}$ ethidium bromide gradient to remove any supercoiled mitochondrial DNA, and labelled by nick translation. Sample $a$, marker $\lambda$ DNA HindIII digest (nick-translated $\lambda$ DNA was included in the probes); $b$, pLmE12 HinfI digest; $c$, pLmE14-4.8 HinfI digest; $d$, pLmE14-8.5 HindIII digest. $B$, heteroduplex analysis ${ }^{22.23}$ showing sequence homology between the clones $\lambda \mathrm{Lm} 12$ and $\lambda \mathrm{Lm} 14$. L, $R$, left and right arms of the $\lambda$ Charon 4 vector. Arrows mark snapbacks.

The relationships of the cloned sequences to nuclear and mitochondrial DNA were examined by Southern blotting (Fig. 3). EcoRI digests of nuclear DNA probed with pLmE12, pLmE14-4.8 and pLmE14-8.5 (Fig. 3A) showed, in each case, a diffuse pattern of hybridization, suggesting homology with highly repeated sequences in the nuclear genome. The hybridization pattern was similar for $H$ indIII and $X b a I$ digests of nuclear DNA (not shown). In the presence of strong repeated sequence

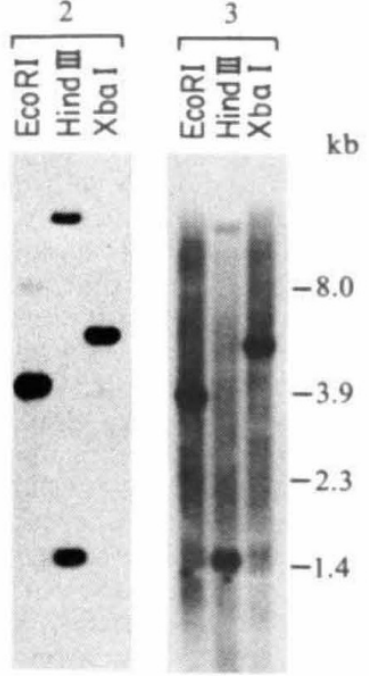

$B$
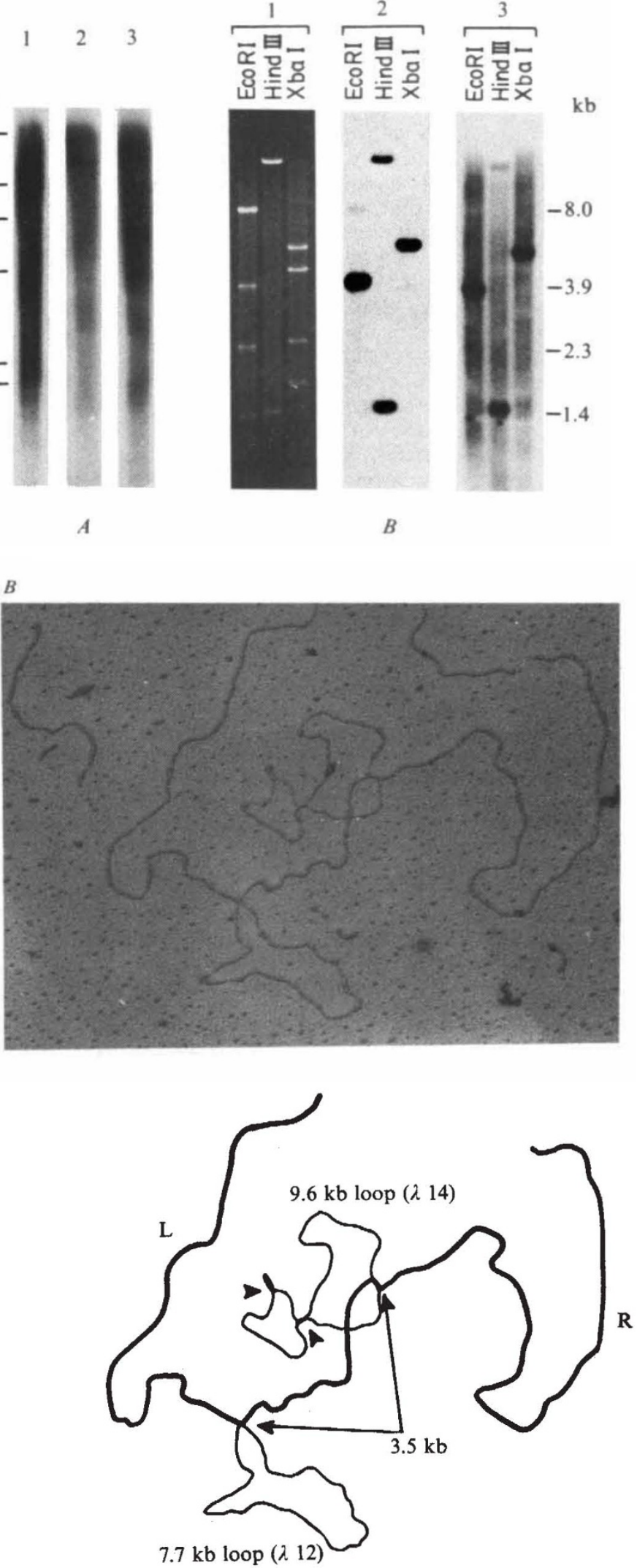

hybridization, one would not expect to detect hybridization with unique sequence nuclear DNA fragments. Homology between the clones and Locusta mitochondrial DNA is examined in Fig. 3B. Blots of a preparation enriched for mitochondrial DNA probed with either pLmE12 (Fig. 3B, panel 2) or pLmE14-4.8 (Fig. 3B, panel 3) showed hybridization to the $3.9-\mathrm{kb}$ EcoRI fragment, both HindIII fragments and the 5.6-kb $\mathrm{XbaI}$ fragment. Background hybridization in Fig. $3 B$, 
panel 3, is due to contamination of the mitochondrial preparation with nuclear DNA. In addition, pLmE12 hybridized weakly to the 8.0-kb EcoRI fragment, suggesting that a small region of homology is shared between the subclone and this mitochondrial fragment. Probing with pLmE14-8.5 (not shown) revealed no homology with mitochondrial DNA. The results indicate that $\lambda \mathrm{Lm} 12$ and $\lambda \mathrm{Lm} 14$ originated from nuclear DNA but contain sequences homologous to portions of the mitochondrial genome. We note that, although restriction mapping shows $\lambda \mathrm{Lm} 12$ and $\lambda \mathrm{Lm} 14$ to represent different sequences from the Locusta genome, they show homology with the same restriction fragments of mitochondrial DNA.

The sequences in the clones were further characterized by the experiments shown in Fig. 4. Southern blots of digests of pLmE12 and pLmE14-4.8 showed fragments homologous with mitochondrial DNA, whereas the digest of pLmE14-8.5 did not (Fig. 4A, panel 2; a faint band in lane $d$ is probably due to a trace of nuclear DNA in the mitochondrial DNA probe). When probed with nuclear DNA, sequences from pLmE12 hybridized moderately strongly, and one HinfI fragment of pLmE14-4.8 and two large HindIII fragments of pLmE14-8.5 reacted strongly. This confirms the presence in the clones of sequences homologous with highly repeated nuclear DNA sequences, as suggested by the genomic Southern blots (Fig. 3 ), and shows that, in $\lambda \mathrm{Lm} 14$, these extend from the right flank of the region of mitochondrial homology. Heteroduplex formation between $\lambda \mathrm{Lm} 12$ and $\lambda \mathrm{Lm} 14$ (Fig. $4 B$ ) showed homology between the two clones in the region that bears homology with mitochondrial DNA, even though their restriction patterns differ. The 3.5-kb stretch of heteroduplex formation matches this region. This result was confirmed by Southern hybridization tests between $\lambda$ Lm12 and pLmE14-4.8 (not shown). Snapback structures within $\lambda \mathrm{Lm} 14$ indicate the presence of inverted repeats, consistent with the presence of highly repeated sequences flanking the regions of homology with mitochondrial DNA.

The data presented demonstrate the presence, in the nuclear genome of a locust, of sequences homologous to mitochondrial DNA, including mitochondrial rRNA genes. The nuclear sequences seem to be moderately repeated, as several crosshybridizing clones were found. Divergence of the homologous sequences, however, is shown by the lack of correspondence in the restriction maps of two clones and the mitochondrial DNA. The presence of highly repeated sequences in the nuclear clones flanking the mitochondrial homologous regions suggests a role in sequence mobility, as postulated for other mobile DNA elements ${ }^{8}$.

Since this work was done, we have learned that mitochondrial DNA sequences are also represented in the nuclear genome of a sea urchin $($ H. T. Jacobs, J. W. Posakony and E. H. Davidson, personal communication). Assuming the independent origin of the mitochondrial genome, transposition of sequences from it into the nuclear DNA, followed by divergence, is the most likely interpretation of these observations. The evidence for mobility of DNA elements within genomes ${ }^{8}$ and between species $^{9}$ is thus extended by evidence for mobility between organelles. A report on homology between mitochondrial and chloroplast DNAs in maize ${ }^{10.11}$, published since submission of this manuscript, leads to similar conclusions.

We thank Elizabeth Belland for RNA from locust tissues, and members of the laboratory for criticism and discussion. The research was supported by grants from the Natural Sciences and Engineering Research Council of Canada and the US NIH (HD-07159). G.G. was the recipient of a fellowship from the Deutsche Forschungsgemeinschaft.

Received 8 October; accepted 15 December 1982.

1. Margulis, L. Origin of Eukaryotic Cells (Yale University Press, New Haven, 1970).

2. Wallace, D. C. Microbiol. Rev. 46, 208-240 (1982).

3. Gray, M. W. Can. J. Biochem. 60, 157-171 (1982).

4. Gray, M. W. Can. J. Biochem. 60, 157-171 (1982).

5. Wyatt, G. R., Locke, J., Bradfield, J. Y., White, B. N. \& Deeley, R. G. in Juvenile Hormone Biochemistry (eds Pratt, G. E. \& Brooks, G. T.) 299-307 (Elsevier, Amsterdam, 1981)

6. Kleinow, W. in The Biogenesis of Mitochondria (eds Kroon, C. M. \& Saccone, C.) 377-381 (Academic, New York, 1974).

7. Spradling, A., Pardue, M. L. \& Penman, S. J. molec. Biol. 109, 559-587 (1977).
8. Shapiro, J. A. \& Cordell, B. Biol. Cell 43, 31-54 (1982).

9. Lewin, R. Science 217, 42-43 (1982).

10. Stern, D. B. \& Lonsdale, D. M. Nature 299, 698-702 (1982)

11. Ellis, J. Nature 299, 678-679 (1982)

12. Buell, G. N., Wickens, M. P., Payour, F. \& Schimke, R. T. J. biol. Chem. 253, 2471-2482 (1978)

13. Kleinow, W. Hoppe-Seyler's Z. physiol. Chem. 355, 1027-1034 (1974)

14. Clewell, D. B. \& Helinsky, D. T. Proc. natn. Acad. Sci. U.S.A. 62, 1159-1166 (1969).

15. Chinzei, Y., White, B. N. \& Wyatt, G. R. Can. J. Biochem. 60, 243-251 (1982).

16. Bailey, J. M. \& Davidson, N. Analyt. Biochem. 70, 75-85 (1976).

17. Southern, E. M. J. molec. Biol. 98, 503-517 (1975)

18. Rigby, R. W. S., Dieckman, M., Rhodes, C. \& Berg, P. J. molec. Biol. 113, 237-251 (1977).

19. Blin, N. \& Stafford, D. W. Nucleic Acids Res. 3, 2303-2308 (1976).

20. Alwine, J. C., Kemp, D. J. \& Stark, G. R. Proc, natn. Acad. Sci. U.S.A. 74, 5350-5354 (1977).

21. Irvine, D. J. \& Brasch, K. Gen. comp. Endocr. 45, $91-99$ (1981).

22. Davis, R. W., Simon, M. \& Davidson, N. Meth. Enzym. 21, 413-428 (1971).

23. Kidd, S. J. \& Gover, D. M. Cell 19, 103-119 (1980).

\section{Deletion mapping of the inducible promoter of human IFN- $\beta$ gene}

\section{Jan Tavernier, Dirk Gheysen, Fred Duerinck, Jose Van der Heyden \& Walter Fiers}

Laboratory of Molecular Biology, State University of Ghent, B-9000 Ghent, Belgium

Human fibroblast cells produce $\beta$-type interferon only in response to viral infection or treatment with an inducer such as poly $(\mathrm{rI}) \cdot$ poly $(\mathrm{rC})$; this event is most probably controlled at the transcriptional level (for review see ref. 1). To study the induction process, we inserted the human fibroblast interferon (IFN- $\beta$ ) gene, with or without its promoter region, into recombinant simian virus 40 (SV40) plasmid vectors which subsequently were transfected into monkey AP-8 cells. We report here that upon induction with poly(rI) $\cdot \operatorname{poly}(\mathrm{rC})$ there was a 10-30-fold increase in IFN- $\beta$ synthesis. This inducer had no effect on interferon production when the coding region only was inserted into the vector plasmid, which indicates that the promoter region is required for inducibility of this gene. Deletion mapping implicates the region between nucleotides -144 and $-\mathbf{1 8 6}$ from the mRNA initiation site in the specific regulation of the IFN- $\beta$ gene. This region contains a sequence that is remarkably homologous with a consensus sequence found in the $5^{\prime}$ flanking region of steroid hormone responsive genes, which might be involved in binding the progesterone-receptor complex ${ }^{2}$.

Interferons are particularly suitable for the study of eukaryotic gene regulation as the interferon system is widespread among eukaryotic organisms and cell types. The very high specific biological activity of interferons renders them easily detectable. Furthermore, the interferon assay allows one to distinguish between different interferons on the basis of their species specificity. Finally, all interferon types, IFN- $\alpha$ (leukocyte), IFN- $\beta$ (fibroblast) and IFN- $\boldsymbol{\gamma}$ (immune), have been successfully cloned ${ }^{3-10}$ and their chromosomal genes isolated from human DNA libraries ${ }^{11-21}$, providing a set of related but differently regulated genes.

To investigate the role of the human IFN- $\beta$ promoter region on inducibility of the gene by poly $(\mathrm{rI}) \cdot \operatorname{poly}(\mathrm{rC})$, we used an autonomously replicating SV40 plasmid vector, which has several advantages over the integration of the gene into the genome of the recipient cell. First, it is a rapid method which avoids the time-consuming selection of transformed colonies. Second, the neighbouring area of the cloned gene is defined and well known. Because no integration occurs there is no possibility of unexpected influences of surrounding genomic segments. Finally, variability due to instability of the genome of the transformed cell is avoided. Transfection has, however, the time limitation of a lytic cycle so that long treatments such as superinduction are not possible. Figure 1 shows the recombinant constructions used in the experiments described here. A detailed physical and genetic map of the pSV529 expression vector has been given previously ${ }^{22}$. It contains 1.4 genome equivalents of SV40 DNA; due to this partial duplication, 